\title{
COMPARATIVE TECHNICAL AND ECONOMIC STUDY OF DAIRY FARMING SYSTEMS IN WEST DELTA REGION
}

\author{
M.M. I. El-Ashmawy ${ }^{1}$, H.B. Sammour ${ }^{2}$, M.A. Khalil ${ }^{1}$, M.A. El-Wardani ${ }^{1}$ \\ and Y. A. Abdel-Aziz ${ }^{1}$ \\ 1- Animal Production Research Institute, Agricultural Research Center, Ministry \\ of Agriculture, Dokki, Giza, Egypt, 2- Agricultural Economic Research Institute, \\ Agricultural Research Center, Ministry of Agriculture, Dokki, Giza, Egypt
}

\section{SUMMARY}

The study was based on findings obtained from a survey carried out in West Delta Region. Eighty farms were randomly selected and a field survey was done with small, medium and large-scale dairy farms in two districts during 2005 in Al-Behera Governorate (West Delta Region).

The objective of the study was to clarify real problems of animal feeding, production, reproduction and economic efficiency using production resources.

On farm visits and questionnaires to small, medium and large dairy farms were completed to obtain information on daily feeds offered to buffalo, crossbred and local (baladi) cows during both winter and summer seasons. Daily feed allowances were calculated according to nutritional requirements and a comparative study was done between the ongoing feeding regime and the calculated ones.

During winter the intake of DM and CP was higher than the requirements in all farms, while TDN intake was lower. During summer only DM was adequately covered while both TDN and CP intake was lower than the requirements. For largescale this shortage was less than in medium and small dairy farms.

Dairy large animals percentage (\%) for large, medium and small farms was 26.43, 72.07 and 1.50, 47.49, 31.14 and 21.37 and 53.9, 29.7 and 16.4\% for buffalo, crossbred and local (baladi) animals, respectively. The total animal units (AU) were 14.73, 7.89 and 1.71 for large, medium and small farms, respectively.

Lactation length for large farms was 248, 274 and $228 d$, for medium , 259, 275 and $231 d$ and for small dairy farms 249, 257 and $210 d$ for buffalo, crossbred and local (baladi) animals, respectively. The results indicated that milk yield per lactation was 1744, 2467 and $1123 \mathrm{~kg}$ for large, 1835, 2233 and $1106 \mathrm{~kg}$ for medium and 1546, 1872 and $950 \mathrm{~kg}$ for small dairy farms for buffalo, crossbred and local (baladi) animals, respectively. Parity numbers were 2.5, 3.1 and 2.0 for large, 4.0, 3.3 and 4.0 for medium and 3.4, 3.5 and 2.9 for small dairy farms for buffalo, crossbred and local (baladi) animals, , respectively.

Average age of lactating cows was 4.1, 4.4 and 5.0 years for large, 6.6, 5.3 and 6.2 years for medium and 5.4, 5.5 and 4.7 years for small dairy farms for buffalo, crossbred and local (baladi) animals, respectively. Average weight of animals was 572, 462 and $413 \mathrm{~kg}$ for large, 557, 467 and $388 \mathrm{~kg}$ for medium and 499, 430 and $367 \mathrm{~kg}$ for small dairy farms for buffalo, crossbred and local (baladi) animals, , respectively.

Issued by The Egyptian Society of Animal Production 
Average calving interval (CI) was 457, 380 and $407 d$ for large, 445, 395 and 398 $d$ for medium and 450, 400 and $400 d$ for small dairy farms for buffalo, crossbred and local (baladi) animals, respectively.

The economic analysis showed a higher total variable costs for large than medium and small dairy farms, 3747, 3352 and 2724 LE for large, 3329, 3423 and 2612 LE for medium and 3317, 3465 and 2720 LE for small dairy farms for buffalo, crossbred and local (baladi) animals, respectively. The gross margin (GM) of crossbred and local cow increased with sizes, reaching 2090, 2699 and 3418 LE /head) for crossbred, 692, 963 and 1078 LE /head for local cow in small, medium and large dairy farms, respectively. While it was higher for medium than large and small dairy farms being 4019, 3433 and 3239 LE for buffalo, respectively.

In spite of the total cost for the large size farms was higher than medium and small dairy farms, the net revenue was higher for large for crossbred than medium and small dairy farms being 2721, 2052 and 1766 LE for large, medium and small dairy farms, respectively. It was higher for medium for buffalo than small and large dairy farms being 3273, 2890 and 2640 LE, for medium, small and large dairy farms, respectively. Also it was higher for large for local (baladi) animals than small and medium dairy farms being 436, 409 and 372 LE, respectively.

The higher net revenue of large farms for crossbred and medium farms for buffalo was due to better feeding and higher lactations length that increased average milk production.

\section{Keywords: Dairy system, West Delta region, Egypt, economic study INTRODUCTION}

West delta region (Al-Behera Governorate) is a very important region in the agricultural sector especially with dairy animals. The total number of dairy animals of buffaloes and cattle was estimated at 374375 buffaloes representing about $10 \%$ of the total number of buffaloes in Egypt and 562920 heads representing about $13.5 \%$ of the total number of cattle in Egypt, (General Statistic, 2004).

Abdel-Aziz (1992) mentioned that about $95 \%$ of buffalo and cattle population are available in farms of less than 5 feddans and five heads. According to General Statistic (2004), fodder crops in these farms are included as a major component. Some of those farmers are particularly interested in dairy farming and are majority contributing to the milk marketing. Milk production data in Egyptian ministry of agriculture 2003 showed that there is a gap in local milk production of 1279000 tons. This may be attributed to small dairy farms representing the majority of animal population in Egypt, which inefficiently run (General Statistic, 2004).

The objectives of study were to clarify real problems of animal feeding, production and reproduction performance, also to study the factors affecting milk production and evaluation of economic and technical efficiency of using available production resources.

\section{MATERIALS AND METHODS}

Eighty dairy farms were randomly selected and a field study was done with small, medium and large-scale dairy farms in two districts selected randomly during 2005 in Al-Behera Governorate. The farms were divided into three sizes: small, medium and 
large. There were fifty-five farms representing for small, twenty for medium and five for large as shown in Table (1).

Table 1. The criteria of farms

\begin{tabular}{lccc}
\hline Farm size & $\begin{array}{c}\text { Number of } \\
\text { farms }\end{array}$ & $\begin{array}{c}\text { Number of adult } \\
\text { females }\end{array}$ & $\begin{array}{c}\text { Cultivated land } \\
\text { (feddan) }\end{array}$ \\
\hline Small & 55 & $<5$ & $<2$ \\
Medium & 20 & $>5<20$ & $>2<10$ \\
Large & 5 & $>20<50$ & $>10$ \\
\hline
\end{tabular}

The data on farms was collected during October 2005 to March 2006. These farms were more interested in dairy farming. The questionnaire was designed to collect quantitative data related to crop and livestock production including detailed information on the herd, animal feeding, land use, crop rotation and economic parameters.

The study used statistical descriptive and quantitative analysis to calculate economic efficiency measures and average and percentage (\%) of different technical and economic variables.

\section{RESULTS AND DISCUSSION}

\section{Herd composition and structure}

In all farms (small, medium and large) there were buffalo, crossbreed and local (baladi) cows as a large ruminant. Herd structure of different breeds in the farms in all villages visited is shown in table (2). Dairy cattle represented about 61.6, 83.3 and $67.82 \%$ of large ruminant for small, medium and large farms, respectively. On the other hand, small farms were characterized by relatively higher percentage of fattening followed by medium and large farms.

Table 2. Herd structure of different breeds in different farm size as animal unit (AU) and \% of each category

\begin{tabular}{lcccccc}
\hline \multirow{1}{*}{ Animals } & \multicolumn{2}{c}{ Small farm } & \multicolumn{2}{c}{ Medium farm } & \multicolumn{2}{c}{ Large farm } \\
\cline { 2 - 7 } & AU & $\%$ & AU & $\%$ & AU & $\%$ \\
\hline Dairy animals & 1.1 & 61.6 & 6.6 & 83.3 & 9.99 & 67.82 \\
Bull animals & 0.01 & 0.63 & 0.0 & 0.0 & 0.40 & 2.72 \\
Pregnant heifer & 0.11 & 6.69 & 0.33 & 4.18 & 1.50 & 10.18 \\
Heifer 1-2 years & 0.16 & 9.56 & 0.06 & 0.82 & 1.12 & 7.60 \\
Heifer < 1 year & 0.06 & 3.36 & 0.22 & 2.74 & 0.00 & 0.00 \\
Suckling & 0.01 & 0.58 & 0.02 & 0.25 & 0.04 & 0.27 \\
Calves < 6 months & 0.01 & 0.68 & 0.0 & 0.0 & 0.00 & 0.00 \\
Calves < 1 year & 0.10 & 6.02 & 0.1 & 1.06 & 0.70 & 4.75 \\
Fattening1-2 years & 0.19 & 10.91 & 0.6 & 7.62 & 0.98 & 6.65 \\
\hline Total & 1.71 & 100.00 & 7.89 & 100.00 & 14.73 & 100.00 \\
\hline
\end{tabular}

Distribution of dairy animal's types in different farms is shown in table (3), buffaloes, crossbred and local (baladi) cows. Buffaloes are dominant in small $(53.9 \%)$ and medium farms (47.49), while crossbred cows are dominant in large farms $(72.07 \%)$ and baladi cows constitute the lowest proportion, ranging from 1.50 $\%$ in large to $21.37 \%$ in medium farms. Soliman et al.(1982) found that large farms tend to favors cattle over buffalo. Similar results were obtained by Nigm et al. 
(1986), Hathut et al. (1996), Nigm (1996), Aboul-Ela et al. (2000), Tabana (2000) and Shalaby et al. (2005).

Table 3. Percentage of dairy animal types according to farm size

\begin{tabular}{lccc}
\hline Dairy animals & Small & Medium & Large \\
\hline Buffaloes \% & 53.9 & 47.49 & 26.43 \\
Cross \% & 29.7 & 31.14 & 72.07 \\
Local (baladi) \% & 16.4 & 21.37 & 1.50 \\
\hline
\end{tabular}

\section{Dairy animals feeding systems}

Feeding system of the dairy animals for all farms in winter and summer seasons depended mainly on the forage produced in the farms. In winter season, all farms cultivated berseem in relatively large areas, while in summer season they cultivated darawa (fodder maize) in small areas. Farms also used supplementary feeds either as commercial concentrates, grains, grain by-products or homemade mixtures. Supplementary feeds are offered in modest quantities. Some farms especially the large farms used corn silage. Straws were commonly used by most of the farms. All feeds offered to the animals in the different farms were transformed into DM, CP and TDN quantities as shown in tables (1, 2 and 3 in the Annex).

\section{Feed balance}

Data in tables $(4,5$ and 6$)$ show that during winter season the intake of DM and $\mathrm{CP}$ was higher than the requirements in all dairy farms, while TDN intake was lower. But during summer season only DM was covered while both TDN and CP intake was lower than the requirements. For large-scale farms this shortage was less identified than in medium and small farms. The results show that offered DM was generally higher in winter than in summer season. Offered CP and TDN was in negative balance from the reference standard in summer season in the three different sizes of farms. These results could be explained by the abundant supply of berseem (high in $\mathrm{CP}$ content) in winter season and limited supply of summer forage (poor in $\mathrm{CP}$ ).

These unbalances in feed requirements during both seasons (winter and summer) have direct impact on productive and reproductive performance of dairy animals (Hathout et al., 1996; Aboul-Ela et al., 2000; El-Ashmawy, 2003; and El-Wardani et al., 2005).

\section{Land use and crop rotation}

In Al-Behera, most of the cultivated lands use the surface irrigation system. The common crops cultivated are presented in table (7) and table (8).

Multi-cropping system is common in all target areas where the farmer cultivates two or more crops in one year. In winter season, wheat and berseem area percentage was the highest in all the target areas. Berseem area percentage was higher for large than medium and small farms, while wheat area percentage was smaller for large than medium and small farms. Perhaps small and medium farms use wheat grains for home consumption. Darawa area was about 1.3 to $1.7 \%$ for small and medium farms only. As general observation, small and medium farms were characterized by higher cropping diversity in winter and summer seasons.

Results show the relatively high importance of wheat, rice, vegetables and corn for small and medium farms compared with large farms. Small and medium farms depend on these crops for home consumption. While cotton and onion area 
percentage for large farms are higher than small and medium farms. Perhaps these farms aim at cultivating cash crops to increase their farm income.

Milk production and reproduction parameters

The average total milk yield for each genotype per lactation was calculated from the number of lactating cows existing in a certain period on each farm size. It was calculated by multiplying average daily milk yield by days in milk, and the results are shown in table (9)

Table 4. Daily feeding values intake of dairy animals and its requirements in winter and summer seasons

\begin{tabular}{lcccccc}
\hline \multirow{2}{*}{ Items } & \multicolumn{7}{c}{ Large farms } \\
\cline { 2 - 7 } & \multicolumn{7}{c}{ Winter season } & \multicolumn{3}{c}{ Summer season } \\
\cline { 2 - 7 } & $\begin{array}{l}\text { DM } \\
\mathbf{( k g )}\end{array}$ & $\mathbf{C P} \%$ & $\begin{array}{c}\text { TDN } \\
\text { \%o }\end{array}$ & $\begin{array}{c}\text { DM } \\
\mathbf{( k g )}\end{array}$ & CP \% & TDN \\
& \multicolumn{7}{c}{ Actual feed intake } \\
\hline Buffaloes & 15.05 & 13.12 & 56.17 & 14.61 & 9.59 & 61.86 \\
Crossbred & 14.41 & 12.87 & 55.13 & 11.85 & 9.47 & 62.51 \\
Local cow (baladi) & 12.60 & 11.64 & 61.06 & 9.63 & 8.86 & 58.88 \\
\hline \multicolumn{7}{c}{ Requirements of feeding according to milk production } \\
\hline Buffaloes & 14.15 & 13.0 & 64.0 & 14.15 & 13.0 & 64.0 \\
Crossbred & 11.37 & 12.2 & 62.9 & 11.37 & 12.2 & 62.9 \\
Local cow (baladi) & 8.59 & 11.6 & 62.9 & 8.59 & 11.6 & 62.9 \\
\hline \multicolumn{7}{c}{ Feeding balance } \\
\hline Buffaloes & 0.90 & 0.10 & -7.79 & 0.46 & -3.43 & -2.10 \\
Crossbred & 3.04 & 0.67 & -7.73 & 0.48 & -2.73 & -0.35 \\
Local cow (baladi) & 4.01 & 0.03 & -1.80 & 1.04 & -2.75 & -3.98 \\
\hline
\end{tabular}

Table 5. Daily feeding values intake of dairy animals and its requirements in winter and summer seasons

\begin{tabular}{|c|c|c|c|c|c|c|}
\hline \multirow{3}{*}{ Items } & \multicolumn{6}{|c|}{ Medium farms } \\
\hline & \multicolumn{3}{|c|}{ Winter season } & \multicolumn{3}{|c|}{ Summer season } \\
\hline & $\begin{array}{l}\text { DM } \\
\text { (kg) }\end{array}$ & CP \% & $\begin{array}{c}\text { TDN } \\
\%\end{array}$ & $\begin{array}{l}\text { DM } \\
\text { (kg) }\end{array}$ & CP \% & $\begin{array}{c}\text { TDN } \\
\%\end{array}$ \\
\hline \multicolumn{7}{|c|}{ Actual feed intake } \\
\hline Buffaloes & 14.85 & 13.75 & 57.33 & 12.42 & 10.01 & 60.94 \\
\hline Crossbred & 13.64 & 13.86 & 57.31 & 11.84 & 9.67 & 61.44 \\
\hline Local cow (baladi) & 13.22 & 11.53 & 53.14 & 9.90 & 9.83 & 60.76 \\
\hline \multicolumn{7}{|c|}{ Requirements of feeding according to milk production } \\
\hline Buffaloes & 14.15 & 13.0 & 64.0 & 14.15 & 13.0 & 64.0 \\
\hline Crossbred & 11.37 & 12.2 & 62.0 & 11.37 & 12.2 & 62.0 \\
\hline Local cow (baladi) & 8.58 & 11.60 & 62.9 & 8.58 & 11.60 & 62.9 \\
\hline \multicolumn{7}{|c|}{ Feeding balance } \\
\hline Buffaloes & 0.70 & 0.72 & -6.63 & -1.73 & -3.01 & -3.02 \\
\hline Crossbred & 2.26 & 1.66 & -5.55 & 0.46 & -2.53 & -1.42 \\
\hline Local cow (baladi) & 4.63 & -0.08 & -9.72 & 1.31 & -1.78 & -2.10 \\
\hline
\end{tabular}


Table 6. Daily feeding values intake of dairy animals and its requirements in winter and summer seasons

\begin{tabular}{|c|c|c|c|c|c|c|}
\hline \multirow{3}{*}{ Items } & \multicolumn{6}{|c|}{ Small farms } \\
\hline & \multicolumn{3}{|c|}{ Winter season } & \multicolumn{3}{|c|}{ Summer season } \\
\hline & DM (kg) & CP \% & TDN \% & DM (kg) & CP \% & TDN \% \\
\hline \multicolumn{7}{|c|}{ Actual feed intake } \\
\hline Buffaloes & 15.49 & 13.87 & 56.93 & 13.58 & 9.78 & 61.88 \\
\hline Crossbred & 15.59 & 13.91 & 56.80 & 10.31 & 9.86 & 61.52 \\
\hline Local cow (baladi) & 11.12 & 13.56 & 56.91 & 9.90 & 9.00 & 60.00 \\
\hline \multicolumn{7}{|c|}{ Requirements of feeding according to milk production } \\
\hline Buffaloes & 12.71 & 13.1 & 63.6 & 12.71 & 13.1 & 63.6 \\
\hline Crossbred & 10.7 & 12.1 & 62.9 & 10.7 & 12.1 & 62.9 \\
\hline Local cow (baladi) & 8.4 & 11.4 & 62.9 & 8.4 & 11.4 & 62.9 \\
\hline \multicolumn{7}{|c|}{ Feeding balance } \\
\hline Buffaloes & 2.79 & 0.73 & -6.64 & 0.87 & -3.36 & -1.69 \\
\hline Crossbred & 4.88 & 1.78 & -6.06 & -0.40 & -2.27 & -1.34 \\
\hline Local cow (baladi) & 2.71 & 2.16 & -5.95 & 1.49 & -2.40 & -2.86 \\
\hline
\end{tabular}

Table 7. The relative cropping areas occupied by different crops during winter season

\begin{tabular}{lcccccc}
\hline Crops & \multicolumn{2}{c}{ Small } & \multicolumn{2}{c}{ Medium } & \multicolumn{2}{c}{ Large } \\
\cline { 2 - 7 } & $\begin{array}{c}\text { Area } \\
\text { (fedan) }\end{array}$ & $\mathbf{\%}$ & $\begin{array}{c}\text { Area } \\
\text { (fedan) }\end{array}$ & $\%$ & $\begin{array}{c}\text { Area } \\
\text { (fedan) }\end{array}$ & $\%$ \\
\hline Berseem & 37.38 & 37.91 & 26.29 & 37.04 & 49.50 & 43.04 \\
Wheat & 42.73 & 43.34 & 27.98 & 39.42 & 39.50 & 34.35 \\
Bean & 9.17 & 9.30 & 11.00 & 15.50 & 18.00 & 15.65 \\
Onion & 4.00 & 4.06 & 0.00 & 0.00 & 8.00 & 6.96 \\
Potatoes & 2.48 & 2.51 & 1.75 & 2.47 & & \\
Vegetable & 2.83 & 2.87 & 2.96 & 4.17 & & \\
Fodder beet & 0.00 & 0.00 & 1.00 & 1.41 & & 100.00 \\
\hline Total & 98.58 & 100.00 & 70.98 & 100.00 & 115.00 & \\
\hline
\end{tabular}

Table 8. The relative cropping areas occupied by different crops during summer season

\begin{tabular}{lcccccc}
\hline \multirow{2}{*}{ Crops } & \multicolumn{2}{c}{ Small } & \multicolumn{2}{c}{ Medium } & \multicolumn{2}{c}{ Large } \\
\cline { 2 - 7 } & Area (fedan) & $\mathbf{\%}$ & Area (fedan) & $\mathbf{\%}$ & Area (fedan) & \% \\
\hline Corn & 28.9 & 31.0 & 26.0 & 40.6 & 37.5 & 32.6 \\
Cotton & 11.6 & 12.5 & 3.3 & 5.2 & 38.0 & 33.0 \\
Rice & 44.7 & 48.0 & 28.5 & 44.6 & 34.5 & 30.0 \\
Darawa & 1.2 & 1.3 & 1.1 & 1.7 & 0.0 & 0.0 \\
Kedny bean & 3.0 & 3.2 & 3.0 & 4.7 & 0.0 & 0.0 \\
Peanuts & 0.0 & 0.0 & 1.5 & 2.3 & 0.0 & 0.0 \\
Elephant grass & 0.3 & 0.3 & 0.0 & 0.0 & 0.0 & 0.0 \\
Watermelon & 1.0 & 1.1 & 0.0 & 0.0 & 0.0 & 0.0 \\
Vegetable & 2.5 & 2.7 & 0.5 & 0.8 & 5.0 & 4.3 \\
\hline Total & 93.2 & 100.0 & 63.9 & 100.0 & 115.0 & 100.0 \\
\hline
\end{tabular}


Table 9. Average milk production and reproduction parameters according to dairy farm size

\begin{tabular}{lccccccccc}
\hline \multicolumn{1}{c}{ Items } & \multicolumn{3}{c}{ Small } & \multicolumn{3}{c}{ Medium } & \multicolumn{3}{c}{ Large } \\
\cline { 2 - 9 } & Buff. & Cross & Local & Buff. & Cross & Local & Buff. & Cross & Local \\
\hline $\begin{array}{l}\text { Av. Milk kg/day } \\
\begin{array}{l}\text { Av. Milk } \\
\text { kg/lactation }\end{array}\end{array}$ & 6.20 & 7.28 & 4.53 & 7.08 & 8.12 & 4.77 & 7.05 & 9.02 & 4.93 \\
$\begin{array}{l}\text { Av. Lactation } \\
\text { length }\end{array}$ & 1546 & 1872 & 950 & 1835 & 2233 & 1106 & 1744 & 2467 & 1123 \\
$\begin{array}{l}\text { Calving interval } \\
\text { (CI) }\end{array}$ & 249 & 257 & 210 & 259 & 275 & 231 & 248 & 274 & 228 \\
$\begin{array}{l}\text { Av. Parity No. } \\
\begin{array}{l}\text { Av. Animal age } \\
\text { year) }\end{array}\end{array}$ & 350 & 400 & 400 & 445 & 395 & 398 & 457 & 380 & 407 \\
$\begin{array}{l}\text { Av. Animal } \\
\text { weight(kg) }\end{array}$ & 5.44 & 3.54 & 2.58 & 4.03 & 3.33 & 3.98 & 2.50 & 3.11 & 2.00 \\
$\begin{array}{l}\text { Av. Animal } \\
\text { value(LE) }\end{array}$ & 500 & 431 & 367 & 557 & 467 & 388 & 572 & 462 & 413 \\
\hline
\end{tabular}

It was noticed that for buffalo, medium farms had the highest average $(1835 \mathrm{~kg} / \mathrm{L})$ followed by large farms $(1744 \mathrm{~kg} / \mathrm{L})$ while small farms had the lowest average $(1546$ $\mathrm{kg} / \mathrm{L})$. For crossbred animals, large farms had the highest average $(2467 \mathrm{~kg} / \mathrm{L})$ followed by medium farms $(2233 \mathrm{~kg} / \mathrm{L})$, while small farms had the lowest average $(1872 \mathrm{~kg} / \mathrm{L})$. The same trend is noticed for local cattle where the large farms had the highest average $(1123 \mathrm{~kg} / \mathrm{L})$ followed by medium farms $(1106 \mathrm{~kg} / \mathrm{L})$ while small farms had the lowest average $(950 \mathrm{~kg} / \mathrm{L})$. The variation between the different sizes could be attributed to genetic, feeding and management differences. Comparing buffaloes with crossbred or local cattle, it can be stated that buffalo performance is high, considering its higher milk fat percentage. This may be attributed to the interest and intensive care of mainly the small and medium farms. Nigm, et al., (1986) found that small livestock holdings in Delta had an average total milk yield of $1246 \mathrm{~kg}$ for buffalo and $638 \mathrm{~kg}$ for baladi cows. Hathout, et al., (1996) reported an average total milk production in the Delta region of 1791 for buffalo and $2279 \mathrm{~kg}$ for crossbred cows. Nigm, (1996) found that total milk yield $(\mathrm{kg})$ for buffalo ranged from 1227 to $2160 \mathrm{~kg}$. Shalaby, et al. (2005) stated that smallholding dairy farms in Ismailia Governorate had an average total milk yield of $1783 \mathrm{~kg}$ for buffalo, $2350 \mathrm{~kg}$ for crossbred and $1286 \mathrm{~kg}$ for baladi cows.

The results in table (9) show that calving interval (CI) was shortest for crossbred cows (380 days) for large farms, while the longest calving interval was (457 days) for buffalo in large farms. Buffalo was longer than baladi or crossbred cows because of gestation period in buffalo is one month or longer than cows. Similar results were observed with small livestock holding by Nigm et al., (1986), Hathout et al., (1996), Aboul-Ela et al., (2000), El-Wardani et al., (2000) and Shalaby, et al. (2005).

\section{Economics of production of milk farms}

\section{Relative importance of the items of revenues structure}

Table (10) shows the relative importance of elements of revenues structure for milk animals, distributed according to farm size. The total revenues from milk and its processed products are considered as the main source and came in the first place among the items of farm revenues, as it represents about $53.45 \%, 67.11 \%, 64.82 \%$ of 
total revenues, in case of small farms. The corresponding figures for medium farms were about $53.42 \%, 69.91 \%, 68.19 \%$ and about $58.53 \%, 69.68 \%, 69.73 \%$ for large farms for each of local cows, buffaloes and cross cows, respectively.

Table 10. Dairy animals revenue and relative importance of revenue items distributed according to farm size in Al-Behera (LE / head / year)

\begin{tabular}{|c|c|c|c|c|c|c|}
\hline \multirow{3}{*}{ Revenue Items } & \multicolumn{6}{|c|}{ Small farms } \\
\hline & \multicolumn{2}{|c|}{ Buffalo } & \multicolumn{2}{|c|}{ Crossbred } & \multicolumn{2}{|c|}{ Local (baladi) } \\
\hline & Value & $\%$ & Value & $\%$ & Value & $\%$ \\
\hline - Milk & 4400.31 & 67.11 & 3600.19 & 64.82 & 1823.94 & 53.45 \\
\hline - Calves & 1260.00 & 19.22 & 1200.00 & 21.61 & 1000.00 & 29.30 \\
\hline $\begin{array}{l}\text { - Change in dairy } \\
\text { animals value }\end{array}$ & 463.00 & 7.06 & 360.00 & 6.48 & 293.00 & 8.59 \\
\hline - Manure & 433.53 & 6.61 & 394.06 & 7.09 & 295.50 & 8.66 \\
\hline \multirow[t]{2}{*}{ Total revenue } & 6556.84 & 100.00 & 5554.25 & 100.00 & 3412.44 & 100.00 \\
\hline & \multicolumn{6}{|c|}{ Medium farms } \\
\hline - Milk & 5291.47 & 69.91 & 4310.34 & 68.19 & 1965.91 & 53.42 \\
\hline - Calves & 1300.00 & 17.18 & 1225.00 & 19.38 & 1100.00 & 29.89 \\
\hline - Change in dairy & 544.00 & 7.19 & 392.00 & 6.20 & 319.00 & 8.67 \\
\hline $\begin{array}{l}\text { animals value } \\
\text { - Manure }\end{array}$ & 433.53 & 5.73 & 394.06 & 6.23 & 295.50 & 8.03 \\
\hline \multirow[t]{2}{*}{ Total revenue } & 7569.00 & 100.00 & 6321.40 & 100.00 & 3680.41 & 100.00 \\
\hline & \multicolumn{6}{|c|}{ Large farms } \\
\hline - Milk & 5003.13 & 69.68 & 4720.80 & 69.73 & 2148.86 & 56.53 \\
\hline - Calves & 1265.00 & 17.62 & 1240.00 & 18.32 & 1050.00 & 27.62 \\
\hline $\begin{array}{l}\text { - Change in dairy } \\
\text { animals value }\end{array}$ & 478.00 & 6.66 & 415.00 & 6.13 & 307.00 & 8.08 \\
\hline - Manure & 433.53 & 6.04 & 394.06 & 5.82 & 295.50 & 7.77 \\
\hline Total revenue & 7179.66 & 100 & 6769.86 & 100 & 3801.36 & 100 \\
\hline
\end{tabular}

The value of milk revenues achieved per head of buffalo exceeded its equivalent for each of cross and local cows at the level of all sizes of farms, as it reached about 4400, 3600, $1824 \mathrm{LE}$ in case of small farms, and about 5291, 4310, $1966 \mathrm{LE}$ for medium farms, respectively and about 5003, 4721, 2149 LE for large farms per head of buffalo, cross and local cow, respectively. Perhaps, the rise in the revenues of milk and dairy products in case of buffaloes to be more than its equivalent in case of cross cows, although the productivity of the head of cross cow has increased within the lactation period, due to the rise of prices of buffalo milk and its products to be more than those of cow milk (the price of selling of cow milk reached about 1.35 LE whereas, the buffalo milk reached about $2 \mathrm{LE}$ ).

The data presented in the table also indicates that the revenues achieved from the milk and its dairy products is directly proportional to the size of farm in case of cross cows and local cows. Whereas the revenues from milk in medium farms has become more than those of large farms, and also exceeded their equivalent in the small farms in case of buffaloes. In addition, the revenues of milk for the head of buffalo reached about 7569, 7180, 6557 in medium, large and small milk farms, respectively. 
It is also clear from the table that the relative importance of young calves and heifers at the age of weaning, ranking in the second place among the items of the revenues. Also, the value of buffalo calves and heifers has become more than their equivalent of cross and local cows, and the value of calves in the medium and large farms exceeded those of small farms. Perhaps, this is because the medium and large farms offer better feeding, e.g fodders with relatively has higher nutritional value. Moreover, they are more able to choose and buy milk animals with better productive and reproductive efficiency. The value of buffalo calves head reached about 1260 , 1300, 1265 LE.

The average of yearly estimated changes of the large milk animal value, as animal fixed assets, its relative importance ranked in the third place among the items of milk animal revenues. It is noted from the table that the value of change in case of buffaloes exceeded its equivalent in case of cross and local cows and its value in large and medium farms exceeded that of small farms.

The value of manure, although its relative importance came after the item of revenues related to the change of large animal value, the value of the two revenue items has approximated to a far extent. The value of manure for buffaloes being higher than its equivalent for cross and local cow is be because of the higher production from buffaloes than cattle, the average production being $28.1,25.5,19.1$ cubic meters in case of dust-floor sheds and 17.22, 15.65, 11.73 cubic meters in case of cement-floor sheds for buffalo and cross and local cows, respectively. In general, the total milk cattle revenues increased according with the size of farm in case of cross and local cows as it reached about 5554, 6321, 6770 LE per head of cross and about 3412 , 3680, $3801 \mathrm{LE}$ per head of local cow in each of small, medium and large milk farms, respectively. Whereas, total revenues of the head of buffalo in medium farms exceeded its equivalent in each of large and small milk farms as it reached about 7569, 7180, 6557 LE, respectively. Large farms probably excelled by achieving higher revenues from cross than from its equivalent in other farms, because of their productive and economic efficiency and their technical experience in breeding that type of animals, represented in better feeding, health and reproductive management .

Also, the data in the table indicates that the total revenues achieved by the head of buffalo has exceeded its equivalent for each of cross and local cows. Excellence of buffaloes can be due to the high price of buffalo milk and its products and high prices of calves and heifers sold at the age of weaning and also the yearly change value for the head of dairy animals and value of manure.

\section{Relative importance of items of variable and fixed costs' structure}

The total costs increase by increasing the size of milk farms at the level of all types of milk cattle as it reached about 3789, 4083, 4048 LE per head of cross (Table 11), about 3666, 4075, 4539 LE per head of buffalo and about 3004, 3204, 3366 LE per head of local cow, in each of small, medium and large farms. Total costs of the head in case of cross, exceeded its equivalent in case of buffalo in small and medium farms. Whereas, it was lower than its equivalent in large farms. Consequently, total costs of the head of local cow decreased at the level of all sizes of farms and became lower than those of buffalo and cross. Total variable costs per head represent the higher percentage of total costs for all types of milk animals. In addition, its relative 
importance is inversely proportional to the size of farms as it reached its highest percentage in small farms, then medium then large farms.

Table 11. The relative importance of variable and fixed costs for dairy animal in Al-Behera (LE/head/year)

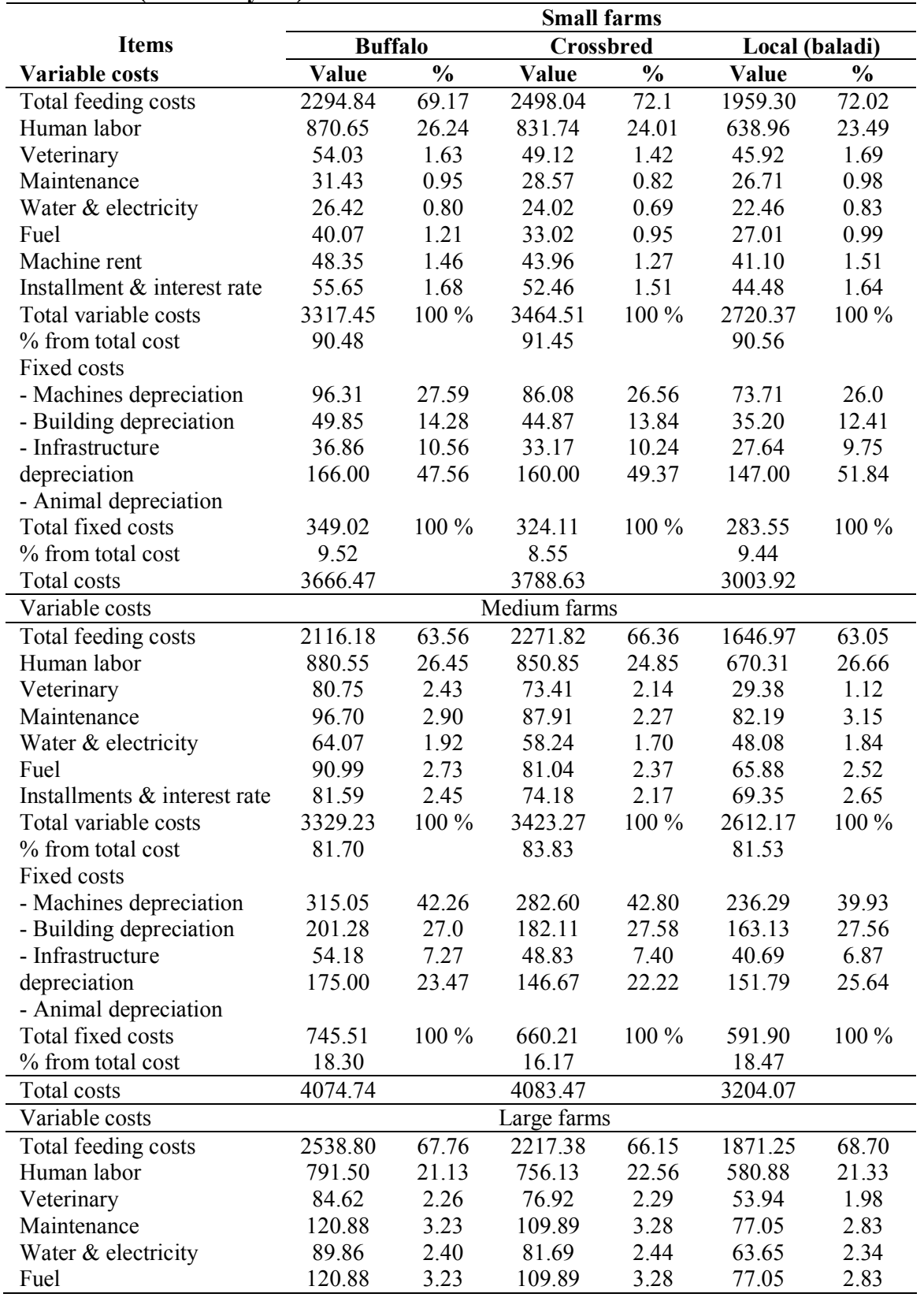


Table 11. Cont.

\begin{tabular}{lcccccc}
\hline \multirow{1}{*}{\multicolumn{1}{c}{ Items }} & \multicolumn{6}{c}{ Large farms } \\
\cline { 2 - 7 } Variable costs & \multicolumn{2}{c}{ Buffalo } & \multicolumn{2}{c}{ Crossbred } & \multicolumn{2}{c}{ Local (baladi) } \\
\cline { 2 - 7 } & Value & \% & Value & \% & Value & $\%$ \\
\hline Total variable costs & 3746.54 & $100 \%$ & 3351.90 & $100 \%$ & 2723.82 & $100 \%$ \\
\% from total cost & 82.53 & & 82.79 & & 80.93 & \\
Fixed costs & & & & & & \\
- Machines depreciation & 331.50 & 41.81 & 271.23 & 38.91 & 281.75 & 43.89 \\
- Building depreciation & 231.46 & 29.19 & 210.42 & 30.19 & 157.82 & 24.58 \\
- Infrastructure & 49.89 & 6.29 & 45.35 & 6.51 & 42.40 & 6.61 \\
depreciation & 180.00 & 22.70 & 170.00 & 24.39 & 160.00 & 24.92 \\
- Animal depreciation & 792.85 & $100 \%$ & 697.00 & $100 \%$ & 641.97 & $100 \%$ \\
Total fixed costs & 17.47 & \multicolumn{5}{c}{17.21} \\
\% from total cost & 4539.39 & 4048.90 \\
\hline Total costs & \multicolumn{7}{c}{3365.79} \\
\hline Machines depreciation includes: Tractors ' Irrigation machines ' milk cans ' cutting machines ' \\
pick up ' Others
\end{tabular}

As for the fixed costs, as opposed to the direction taken by the relative importance of variable costs, results show that it is directly proportional to the size of the farm either in its absolute value or according to its relative importance from the total costs. This relationship can be due to the higher value of fixed assets (represented in buildings, machines, infrastructure and value of animal assets) in large farms than its equivalents in each of medium and small farms. The relative importance of fixed costs to the total costs per the head of milk animals is about $9.4 \%, 9.5 \%, 8.6 \%$ in small farms. It increased and reached about $18.5 \%, 18.3 \%, 16.2 \%$ in medium farms and increased reaching about $19.1 \%, 17.5 \%, 17.2 \%$ in large farms for each of local cows, buffaloes and cross, respectively. Through analysis the elements of variable costs in milk farms, it is plain that feeding costs per head comes in the first place then followed in importance by human labor costs, then other items of variable costs. As the relative importance of feeding costs to the total variable costs reached about $72 \%$, $69.2 \%, 72.1 \%$ in small farms. And about $63.1 \%, 63.6 \%, 66.4 \%$ in medium farms and about $68.7 \%, 67.8 \%, 66.2 \%$ in large farms for local cow, buffalo and cross, respectively.

\section{Costs of feeding milk animals and costs of human labor}

Since the costs of feeding milk animals and costs of labor represent the higher percentage of total variable costs as stated before, and they also represent two important elements of systems of feeding milk animals and have a considerable effect on production costs and revenues, the present study handles these two production resources by analyzing them in more details than other production resources. Feeding costs per head of cross decreased with the increase in the size of farm (Table 11) and their relative importance is inversely proportional to the size of farm. This relationship between feeding costs of cross and size of farms is probably due to that the amounts and types of feeds used in small farms included more amounts of concentrates (high-priced) and green forages than fodders used in large farms. Whereas, amounts used of straw were similar in both sizes of farms. Also, the large farms used lower amounts of green forages, besides using the low-priced silage, knowing that silage is considered as an economic resource with high nutritional value and an alternative of concentrates (Table no. 1, 2 and 3 in annex) which in turn, had a 
positive influence on cross productivity, as it reached about 7.28, 8.12, $9.02 \mathrm{~kg}$ per head per day for each of small, medium and large farms, respectively (Table . 9). As for the feeding costs of local cows they were the highest per head per year in small milk farms and it reached the minimum average in medium farms, whereas the large farms were intermediate. .

Also, the relative importance of feeding costs for the head from total variable costs has taken the same course according to the size of farms as it reached about $72 \%, 69 \%, 63 \%$, respectively, and the rise in the feeding costs of the head in small farms may be due to the increase of the amounts used of concentrates and roughages that are higher-priced than the amounts used of the two resources in large farms. The large farms used silage instead of high-priced concentrates and straw, which in turn, had a considerable effect on increasing the milk productivity per head of local cows in large farms more than its equivalent in medium and small farm, as it reached about 4.53, 4.77, $4.93 \mathrm{~kg}$ per head, respectively (Table 9and 1, 2 and 3 in Annex). As for the feeding costs for the head of buffalo, it has taken a different course than that of cross and local cow, as it reached its maximum value in large farms, and its minimum value in medium farms, whereas the small farms were intermediate, reaching about 2539, 2295, 2116 LE per head in large, small and medium farms, respectively.

Table (12) that number of human labor days within the year (including different animal production processes) per head of buffalo is higher than its equivalent in case of cross and local cow as it reached about 64.04, 61.88, $48.75 \mathrm{man} / \mathrm{day}$, and estimated at 800.6, 773.5, 609.4 LE, respectively.

Table 12. Human labor distributed according to animal breeds and animal work items

\begin{tabular}{lcccccc}
\hline Type of animal work & Buffalo & $\mathbf{\%}$ & Local & \% & Cross & $\%$ \\
\hline Berseem cutting & 44.28 & 8.64 & 30.19 & 7.74 & 40.25 & 8.13 \\
Darawa cutting & 8.97 & 1.75 & 6.11 & 1.57 & 8.15 & 1.65 \\
Dusting under the animals & 30.11 & 5.88 & 20.53 & 5.26 & 27.38 & 5.53 \\
Manure collection & 54.05 & 10.55 & 36.86 & 9.45 & 49.14 & 9.93 \\
Animal feeding & 100.38 & 19.59 & 68.44 & 17.55 & 91.25 & 18.43 \\
Animal drinking & 100.38 & 19.59 & 68.44 & 17.55 & 91.25 & 18.43 \\
Animal milking & 174.20 & 34.00 & 159.46 & 40.88 & 187.60 & 37.90 \\
Hours/ head/year & 512.36 & 100.00 & 390.02 & 100.00 & 495.02 & 100.00 \\
Man/day & 64.04 & & 48.75 & & 61.88 & \\
LE/head/year & 800.56 & & 609.41 & & 773.46 & \\
\hline
\end{tabular}

Results shown in the table points out to the relative importance of animal production processes.. Milking processes demand the highest number of labor hours from total hours of yearly labor. Number of hours of milking processes per head of cross is more than its equivalent in case of buffalo and local cows as it reached 187.6, 174.2 , 159.5 hour of labor, representing about $37.9 \%, 34 \%, 40.9 \%$ of total labor hours, respectively. The relative importance of labor concerning feeding and watering the animals, was the same for all types of animals, and in the second place after animal milking process. Number of labor hours concerning buffaloes for both feeding and watering the animals, is more than its equivalent for cross and local cow , 
respectively, as it reached about $100.38,91.25,68.44$ per year for each process alone. The relative importance of the process of dusting and collection of manure comes in the third place as the relative importance of these two processes together, reaching about $16.43 \%, 15.46 \%, 14.71 \%$ of total labor hours per year for the head of buffalo, cross and local cow , respectively..

The relative importance of total number of family labor hours in medium milk farms has come in the first place followed by small then large farms as it reached about $93.93 \%, 88.61 \%, 60.97 \%$ of total number of labor hours at the level of the farm, respectively (Table 13). As opposed to this, the relative importance of rented labor reached its maximum value in large farms followed by small then medium farms as it reached about $39.03 \%, 11.39 \%, 6.07 \%$, respectively. So in brief, rented human labor contributes with a larger portion in large farms than its equivalent in medium and small farms. Whereas, family labor contributes in these farms with a bigger portion than its equivalent in large farms.

Table 13. Human labor distributed according to its performance per farm (hours/year)

\begin{tabular}{lcccccc}
\hline Farm size & \multicolumn{2}{c}{ Small } & \multicolumn{2}{c}{ Medium } & \multicolumn{2}{c}{ Large } \\
\cline { 2 - 7 } Types of human labor & No. hours & \% & No. hours & \% & No. hours & \% \\
\hline Family & 733.26 & 88.61 & 3668.56 & 93.93 & 4337.9 & 60.97 \\
Rented & 94.24 & 11.39 & 237.11 & 6.07 & 2776.69 & 39.03 \\
Total & 827.5 & 100 & 3905.67 & 100 & 7114.59 & 100 \\
Men & 142.15 & 17.18 & 1139.51 & 29.18 & 1224.52 & 17.21 \\
Women & 368.25 & 44.50 & 1856.54 & 47.53 & 3172.14 & 44.59 \\
Boys & 317.1 & 38.32 & 909.62 & 23.29 & 2717.93 & 38.20 \\
Total & 827.5 & 100 & 3905.67 & 100 & 7114.59 & 100 \\
\hline
\end{tabular}

Date shown in Table no. (13) indicates to the labor distribution according to its performers of men, women and children. It becomes clear from this table that women contribute with a large portion in the field of milk production processes at the level of all farms' sizes as the relative importance of women's labor reached about $44.5 \%$, $47.53 \%, 44.59 \%$ of total number of hours of animal herd labor for small, medium and large farms, respectively. The relative importance of men's labor is lower in small and large farms than that of children's labor, which follows the relative importance of women's labor. These ratios were alike to a good extent in these farms reaching $17.18 \%, 17.21 \%$ for men, and about $38.32 \%, 38.20 \%$ for children in small and large farms, respectively. As for men's labor in medium farms, its relative importance was higher than that of children's labor exceeding its equivalent in small and medium farms.

The data indicated that women only do the milking, while they contribute to other processes like animal feeding, animal dusting and cutting barseem, while men and children help her through these processes. Darawa cutting and collection of manure are done by men and children only. This system of distributing the human labor over the different processes was similar across all farm sizes.

\section{Economic efficiency of milk farms}

\section{Gross Margin}

Gross margin of cross and local cow increases with the sizes of the farm as it reached about 2090, 2699, $3418 \mathrm{LE} /$ head of cross (Table 14) and about 692, 963, 
$1078 \mathrm{LE} /$ head of local cow in small, medium and large farms, respectively. Meaning that large farms in case of cross and local cows are considered to be the most efficient farms as related to this measure. Buffalo farms are considered to be the more efficient than the others as this measure reached about 4019, 3433, 3239 LE per head, for medium, large and small farms, respectively. Comparing the economic efficiency of the types of milk animals, the buffaloes are the most efficient, followed by cross, then local cows as the gross margin pere head reached $3239,4019,3433$ LE in case of buffaloes. It was lower in case of cross reaching 2090, 2699, 3418 LE. Then it decreased a far extent in case of local cow reaching 692, 964, 1078 for small, medium and large milk farms, respectively. The value of this measure in case of buffaloes was higher by $155 \%, 149 \%, 100.4 \%$ than cross, and by $468 \%, 416 \%, 318 \%$ than local cow for the farms' sizes previously pointed out.

\section{Net Revenue}

The net revenue of per head of cross increased with farm size as it reached 1766, 2052, 2721 LE for small, medium and large farms, respectively. As for local cows, net revenue per head in large farms was higher than its equivalent in small and medium farms being 436, 409, 372 LE. Meaning that, the value of this measure in large farms is slightly higher than that in small and medium farms by $106 \%, 117 \%$, respectively. In brief, the large farms in case of cross and local cows are considered to the most efficient farms as related to this measure. For the buffaloes, the medium farms have exceeded its equivalent in small and large farms as the value of this measure reached about 3273, 2890, 2640 LE per head, respectively. It is also clear from the table that the milking buffaloes are considered to be the most efficient of milk animals in small and medium farms, whereas, cross exceeded it in large farms as it achieved the highest value of this measure.

Calculating the gross margin and net revenue of milk only without the other elements of revenues (value of calves, the change of the value of animal assets and the value of manure), it becomes clear that the local cows have negative values of both measures for all sizes of farms, meaning that, the revenues of milk from the head neither cover the variable costs nor the total costs, and the same thing for cross in small farms only. As for the buffaloes at the level of all sizes of farms and cross in medium and large farms, milk revenues were higher than the variable and total costs, so it achieved positive values for the previous two measures. These negative values of the two measures are probably due to the decrease of the average head productivity and the length of the lactation period for local and cross cows in these farms as they averaged $\mathrm{t} 4.53,7.28 \mathrm{~kg}$, and the length of lactation period reached about 210,257 days, respectively.

\section{Ratio of total revenue/ total variable costs}

Total revenue/variable costs increased with the rise of the sizes of milk farms for each of cross and local cows reaching 1.60, 1.74, 2.02 per head of cross, and about $1.25,1.35,1.40$ for the head of local cows in small, medium and large farms , respectively (Table 14). This measure indicates that the pound being spent on items of variable costs achieves net profits of about $0.60,0.74,1.02 \mathrm{LE}$ for cross, and about $0.25,0.35,0.40$ per head of local cows. Thus, the best efficient farms as related to this measure are the large farms followed by medium farms then small farms. 
Table 14. An important measures of economic efficiency in Al-Behera dairy farms (LE/head/year)

\begin{tabular}{|c|c|c|c|c|c|c|c|c|c|}
\hline \multirow[b]{2}{*}{ Items } & \multicolumn{3}{|c|}{ Small farms } & \multicolumn{3}{|c|}{ Medium farms } & \multicolumn{3}{|c|}{ Large farms } \\
\hline & Buffalo & crossbred & $\begin{array}{c}\text { Local } \\
\text { (baladi) }\end{array}$ & Buffalo & crossbred & $\begin{array}{c}\text { Local } \\
\text { (baladi) }\end{array}$ & Buffalo & crossbred & $\begin{array}{c}\text { Local } \\
\text { (baladi) }\end{array}$ \\
\hline Total revenue & 6556.84 & 5554.25 & 3412.44 & 7569.00 & 6321.40 & 3680.41 & 7179.66 & 6769.86 & 3801.36 \\
\hline Total variable costs & 3317.45 & 3464.51 & 2720.37 & 3549.95 & 3622.65 & 2716.51 & 3746.54 & 3351.90 & 2723.82 \\
\hline Total fixed costs & 349.02 & 324.11 & 283.55 & 745.59 & 647.10 & 591.90 & 792.85 & 697.00 & 641.97 \\
\hline Total costs & 3666.47 & 3788.63 & 3003.92 & 4295.53 & 4269.76 & 3308.42 & 4539.39 & 4048.90 & 3365.79 \\
\hline Gross margin & 3239.39 & 2089.74 & 692.07 & 4019.05 & 2698.74 & 963.90 & 3433.12 & 3417.96 & 1077.54 \\
\hline Net revenue & 2890.37 & 1765.62 & 408.52 & 3273.47 & 2051.64 & 371.99 & 2640.27 & 2720.96 & 435.57 \\
\hline Av. variable costs of milk & 2.15 & 1.85 & 2.86 & 2.02 & 1.62 & 2.46 & 2.10 & 1.43 & 2.12 \\
\hline (LE/kg) & 2.37 & 2.02 & 3.16 & 2.44 & 1.91 & 3.00 & 2.62 & 1.46 & 3.00 \\
\hline Av. Total costs of milk & 1.79 & 1.47 & 1.14 & 1.76 & 1.48 & 1.11 & 1.58 & 1.67 & 1.13 \\
\hline$(\mathrm{LE} / \mathrm{kg})$ & 1.98 & 1.60 & 1.25 & 2.13 & 1.74 & 1.35 & 1.92 & 2.02 & 1.40 \\
\hline Total revenue / T. V. C. & 1082.86 & 135.68 & -896.43 & 1741.52 & 687.68 & -750.60 & 1256.59 & 1368.90 & -574.96 \\
\hline $\begin{array}{l}\text { Total revenue / T. C. } \\
\text { GM from milk (LE) }\end{array}$ & 733.84 & -188.44 & $\begin{array}{c}- \\
1179.98\end{array}$ & 995.94 & 40.58 & $\begin{array}{c}- \\
1342.51\end{array}$ & 463.74 & 671.90 & $\begin{array}{c}- \\
1216.93\end{array}$ \\
\hline
\end{tabular}

Net revenue from milk (LE)

Av. $=$ Average $^{\prime}$ T.V.C. $=$ Total variable cost ${ }^{\prime} \quad$ T.C. $=$ Total cost ${ }^{\prime}$ GM $=$ Gross margin 
As for the buffaloes, the values of this measure indicate that the medium farms are considered to be the best efficient farms as the measure reached about 1.98, 2.13, 1.92 for small, medium and large farms, respectively. And this means that the pound being spent on the items of variable costs achieves net profit about $0.98,1.13,0.92$ LE per head of the farms pointed out. Comparing the economic efficiency of the types of milk animals, it becomes clear that buffaloes in small and medium farms have achieved the highest value of this measure in comparison with the cross and local cows, whereas, the cross achieved the highest value in large farms. These agree with those using the measures of the gross margin and net revenue, which, in turn, indicates that the best efficient farms are the large farms in case of cross and local cows, whereas, the most efficient in case of buffaloes, are the medium farms.

\section{Ratio of total revenue /total costs}

The ratio of total revenue /total costs, increases with farm size in case of cross as it reached about 1.47, 1.48, 1.67 per head, in small, medium and large farms, respectively, which in turn, means that the pound being spent on all the items and elements of total costs, has achieved a net revenue per head that reached about 0.47 , $0.48,0.67 \mathrm{LE}$ for the farm sizes mentioned (Table 14). In local cows, the value of this measure for the different farm sizes approximated averaged 1.14, 1.11, 1.13 for small, medium and large farms, respectively. In buffaloes, the value of this measure decreased with the increase in the farm size, however, its value in small and medium farms was similar as it reached about $1.79,1.76,1.58$, which means that the pound being spent on the items of total costs achieves net revenue averaged about 0.79 , $0.76,0.58 \mathrm{LE}$ per head in small and large farms, respectively.

We conclude from the previous presentation that the large farms in case of cross are considered to be the most efficient farms as related to this measure. And this result regarding the priority of this size of farms, agree with conclusions reached from the three measures of economic efficiency, previously mentioned. As for the milking buffaloes, the results showed that by using this measure, the medium farm is not the best of the farms and that the small farms are slightly better than it, then followed by the large farms. Whereas, the results shown using the measure of the ratio of total revenue/total variable costs indicated that the medium farms are the best, and this may be due to the rise of the total costs in medium and large farms. The rise of the total costs is originally due to the rise of the fixed costs) which means that each of the large and medium farms should breed a larger number of milk-producing animals in order to increase the total revenue.

\section{Average total costs for the unit produced of milk}

This measure indicates the average total costs for each kilogram produced of milk and the decrease of this measure, as opposed to the previous relative measures, is considered as a positive indicator. The value of this measure decreases with the rise in farm size in case of cross and local cows as it reached about 2.02, 1.91, $1.64 \mathrm{LE} / \mathrm{kg}$ for cross, and about $3.16,3,3 \mathrm{LE} / \mathrm{kg}$ for local cows for small, medium and large farms, respectively. Thus, the large milk farms in case of cross and local cows are the most efficient farms as they achieved the minimum average total costs for each kilogram produced of milk. This may be due to the rise of the average productivity of cross and local cows by the rise of the farm sizes, as the average productivity of the 
head reached about 7.28, 8.12, $9.02 \mathrm{~kg}$ for cross, and about 4.53, 4.77, $4.93 \mathrm{~kg}$ for local cows in small, medium and large farms, respectively. In the case of buffaloes, the results of this measure show what is opposite to what preceded in case of cross and local cows, the magnitude of this measure increased with the rise in farm size reaching $2.37,2.44,2.62 \mathrm{LE} / \mathrm{kg}$ milk. The rise of the average costs of the kilogram produced in case of buffaloes, is probably because the rise of the average per head productivity of milk with the rise in the size of the farm, was not adequate enough to coordinate with the rate of the rise of total costs with the rise of the farm size, as was previously pointed out. So, the average cost of the kilogram produced of milk increased. Comparing the economic efficiency for the types of milk animals using this measure, it becomes clear that the most efficient milk animals are the cross, followed by the buffaloes, then local cows. The cross had the minimum average cost for the kilogram produced of milk which may be due to the rise of the average per head productivity of milk, for cross, followed by buffaloes, then local cows.

\section{CONCLUSION}

The study concluded that the best economic efficiency was realized in large dairy farms for crossbreed and local cows. While buffalo in medium dairy farms showed the best net revenue compared with the cross and local cows in the study sample.

\section{REFERENCES}

Abdel-Aziz, A. S., 1992. Characteristics of Egyptian buffalo. Proc. Of the International Symposium of Prospects of Buffalo Production in the Mediterranean and the Middle East. Cairo, 9-12 Nov. Egypt.

Aboul-Ela, M.B., M.A. El-Wardandi, H. Almahdy, 2000. Characterization of management practices of buffaloes raised under traditional condition of small holdings. Proceedings of Animal Production in the $21^{\text {st }}$ Century Challenges and Prospects. Sakha, Kafr El- Sheikh, Egypt. April 18-20.

El-Ashmawy, M. M. I., 2003. Introducing maize silage in winter feeding under dairy animal farm systems in Africa. Ph.D. Thesis, IARS, Cairo University. Cairo, Egypt.

El-Wardani M. A., M. I. El-Ashmawy, M. A. Khalil, Y. A. Abdel-Aziz and M. F. ElSayes, 2005. Feed planning system as integrated package to improve mixed farming system. Proceeding of Second Conference of Animal Production Research Institute and Regional Symposium on Buffalo Production. Sakha, Kafr El-Sheikh. Egypt, Sept.27-29.

El-Wardani M.A., H. Almahdy, A.S. Tabana and M.K., Hathout, 2000. Reproductive performance of the Baladi cows and Buffaloes under traditional management system in Egyptian smallholdings. Animal Production in the 21st Century: Challenges and Prospects. Sakha, Kafr El-Sheikh, Egypt, April 18-20, pp325-333.

General Statistics Year Book, 2004. Ministry of Agriculture and Land Reclamation, Economic Affairs Sector, Central Administration for Economic.

Hathout, M.K., S.A. El-Saadany, A.S. Tabana, M.M. Ismail and I.M. Gomaa, 1996. Dairy farming under crop livestock mixed system in the Delta Region, Egypt. International Symposium on Buffalo Resources and Production Systems. Oct. 1417, 1996, Cairo, Egypt. 
Nigm, A.A., 1996. Characterization of the Egyptian Buffalo. Proceeding of International Symposium on, (Buffalo Resources and Production Systems). Cairo, Egypt, Oct. 14-17, pp.:1-8.

Nigm, A.A., I. Soliman, M. K. Hamed and A. S. Abdel-Aziz, 1986. Milk production and reproductive performance of Egyptian cows and buffaloes in small livestock holdings. Proceeding of the $7^{\text {th }}$ Conference of Animal Production, Cairo, Egypt, Sept. 16-18. pp.: 290-304.

NRC, 1990. Nutrient Requirements of Dairy cattle. National Research Council. $6^{\text {th }}$ rev. ed. Natl. Acad. Sci., Washington, D.C.

Shalaby, T.H., M.A. El-Wardani, H.B. Sammour, M.A. Khalil, A.M. Ahmed and M.F. El-Sayes, 2005. Economic study of different types of dairy cattle under mixed farming system in Egypt. Proceeding of Second Conference of Animal Production Research Institute and Regional Symposium on Buffalo Production. Sakha, Kafr El-Sheikh, Egypt, Sept. 27-29.

Soliman, I and Z. El-Shatat, 1982. Soc-economic factors affecting decision of traditional farmers on investment in livestock in Sharkia governorate. The $7^{\text {th }}$ International congress for statistics, computer science, social and demographic research, Ain-Shams University, Cairo, Egypt, March 27-April 1, pp 1-8.

Tabana, A.S., 2000. Development of a decision support system for individual dairy farm in mixed irrigated farming system in the Nile Delta. Ph.D. Thesis, Wageningen University, Wageningen, The Netherlands.

Annex: Table 1. Average daily feed intake of dairy animals in winter and summer seasons

\begin{tabular}{|c|c|c|c|c|c|c|c|c|c|c|}
\hline \multirow[t]{3}{*}{ Items } & \multicolumn{10}{|c|}{$\begin{array}{c}\text { Large farms } \\
\text { (Buffalo) }\end{array}$} \\
\hline & \multicolumn{5}{|c|}{ Winter season } & \multicolumn{5}{|c|}{ Summer season } \\
\hline & Total & Conc.mix & Berseem & $\begin{array}{l}\text { Corn } \\
\text { silage }\end{array}$ & Straw & Total & Conc.mix & Darawa. & $\begin{array}{l}\text { Corn } \\
\text { silage }\end{array}$ & Straw \\
\hline $\begin{array}{l}\text { Fresh } \\
\text { feed }(\mathrm{kg})\end{array}$ & 56.45 & 3.75 & 48.0 & 0.00 & 4.70 & 39.5 & 3.5 & 18.0 & 14.0 & 4.0 \\
\hline$\%$ & 100.0 & 22.43 & 49.45 & 0.00 & 28.12 & 100.0 & 21.56 & 22.15 & 31.62 & 24.64 \\
\hline DM (kg) & 15.05 & 3.38 & 7.44 & 0.00 & 4.23 & 14.61 & 3.15 & 3.24 & 4.62 & 3.60 \\
\hline $\mathrm{CP} \%$ & 13.12 & 0.54 & 1.26 & 0.00 & 0.17 & 9.59 & 0.50 & 0.29 & 0.46 & 0.14 \\
\hline \multirow[t]{2}{*}{ TDN \% } & 56.17 & 2.30 & 4.46 & 0.00 & 1.69 & 61.86 & 2.14 & 2.27 & 3.19 & 1.44 \\
\hline & \multicolumn{10}{|c|}{ (Crossbred) } \\
\hline $\begin{array}{l}\text { Fresh } \\
\text { feed }(\mathrm{kg})\end{array}$ & 57.4 & 2.50 & 50.0 & 0.0 & 4.90 & 35.5 & 2.50 & 20.0 & 10.0 & 3.0 \\
\hline$\%$ & 100.0 & 15.61 & 53.78 & 0.0 & 30.60 & 100.0 & 18.99 & 30.38 & 27.85 & 22.78 \\
\hline DM (kg) & 14.41 & 2.25 & 7.75 & 0.0 & 4.41 & 11.85 & 2.25 & 3.60 & 3.30 & 2.70 \\
\hline СР \% & 12.87 & 0.36 & 1.32 & 0.0 & 0.18 & 9.47 & 0.36 & 0.33 & 0.33 & 0.11 \\
\hline \multirow[t]{2}{*}{ TDN \% } & 55.13 & 1.53 & 4.65 & 0.0 & 1.76 & 62.51 & 1.53 & 2.28 & 2.28 & 1.08 \\
\hline & \multicolumn{10}{|c|}{ Local (baladi) } \\
\hline $\begin{array}{l}\text { Fresh } \\
\text { feed }(\mathrm{kg})\end{array}$ & 44.0 & 1.50 & 24.0 & 16.0 & 2.50 & 28.3 & 2.5 & 22.0 & 0.0 & 3.8 \\
\hline$\%$ & 100.0 & 10.71 & 29.52 & 41.90 & 17.86 & 100.0 & 23.36 & 41.12 & 0.0 & 35.51 \\
\hline DM (kg) & 12.60 & 1.35 & 3.72 & 5.28 & 2.25 & 9.63 & 2.25 & 3.96 & 0.0 & 3.42 \\
\hline $\mathrm{CP} \%$ & 11.64 & 0.22 & 0.63 & 0.53 & 0.09 & 8.86 & 0.36 & 0.36 & 0.0 & 0.14 \\
\hline TDN \% & 61.06 & 0.92 & 2.23 & 3.64 & 0.90 & 58.88 & 1.53 & 2.77 & 0.0 & 1.37 \\
\hline
\end{tabular}


Annex: Table 2. Average daily feed intake of dairy animals in winter and summer seasons

\begin{tabular}{|c|c|c|c|c|c|c|c|c|c|c|}
\hline \multirow[t]{3}{*}{ Items } & \multicolumn{10}{|c|}{$\begin{array}{l}\text { Medium farms } \\
\text { (Buffalo) }\end{array}$} \\
\hline & \multicolumn{5}{|c|}{ Winter season } & \multicolumn{5}{|c|}{ Summer season } \\
\hline & Total & $\begin{array}{l}\text { Conc. } \\
\operatorname{mix}\end{array}$ & Berseem & $\begin{array}{l}\text { Corn } \\
\text { silage }\end{array}$ & Straw & Total & $\begin{array}{l}\text { Conc. } \\
\operatorname{mix}\end{array}$ & Darawa & $\begin{array}{l}\text { Corn } \\
\text { silage }\end{array}$ & Straw \\
\hline Fresh feed (kg) & 67.65 & 1.75 & 59.50 & 3.0 & 3.40 & 34.7 & 4.8 & 26.0 & 0.0 & 3.9 \\
\hline$\%$ & 100.0 & 10.61 & 62.11 & 6.67 & 20.61 & 100.0 & 34.42 & 37.68 & 0.0 & 27.90 \\
\hline $\mathrm{DM}(\mathrm{kg})$ & 14.85 & 1.58 & 9.22 & 0.99 & 3.06 & 12.42 & 4.28 & 4.68 & 0.0 & 3.47 \\
\hline $\mathrm{CP} \%$ & 13.75 & 0.25 & 1.57 & 0.10 & 0.12 & 10.01 & 0.68 & 0.42 & 0.0 & 0.14 \\
\hline TDN \% & 57.33 & 1.07 & 5.53 & 0.68 & $\begin{array}{l}1.22 \\
\text { (Cros }\end{array}$ & $\begin{array}{l}60.94 \\
\text { red) }\end{array}$ & 2.91 & 3.28 & 0.0 & 1.39 \\
\hline Fresh feed $(\mathrm{kg})$ & 55.3 & 3.40 & 48.50 & 0.0 & 3.40 & 36.8 & 3.8 & 29.5 & 0.0 & 3.5 \\
\hline$\%$ & 100.0 & 22.44 & 55.12 & 0.0 & 22.44 & 100.0 & 28.52 & 44.87 & 0.0 & 26.62 \\
\hline DM (kg) & 13.64 & 3.06 & 7.52 & 0.0 & 3.06 & 11.84 & 3.38 & 5.31 & 0.0 & 3.15 \\
\hline $\mathrm{CP} \%$ & 13.86 & 0.49 & 1.28 & 0.0 & 0.12 & 9.67 & 0.54 & 0.48 & 0.0 & 0.13 \\
\hline TDN \% & 57.31 & 2.08 & 4.51 & 0.0 & 1.22 & 61.44 & 2.30 & 3.72 & 0.0 & 1.26 \\
\hline & \multicolumn{10}{|c|}{ Local (baladi) } \\
\hline Fresh feed $(\mathrm{kg})$ & 44.9 & 2.40 & 36.50 & 0.0 & 6.0 & 28.3 & 3.6 & 21.5 & 0.0 & 3.2 \\
\hline$\%$ & 100.0 & 16.34 & 42.80 & 0.0 & 40.85 & 100.0 & 32.27 & 39.09 & 0.0 & 28.64 \\
\hline DM (kg) & 13.22 & 2.16 & 5.66 & 0.0 & 5.40 & 9.90 & 3.20 & 3.87 & 0.0 & 2.84 \\
\hline $\mathrm{CP} \%$ & 11.53 & 0.35 & 0.96 & 0.0 & 0.22 & 9.83 & 0.51 & 0.35 & 0.0 & 0.11 \\
\hline TDN \% & 53.14 & 1.47 & 3.39 & 0.0 & 2.16 & 60.76 & 2.17 & 2.71 & 0.0 & 1.13 \\
\hline
\end{tabular}

Annex: Table 3. Average daily feed intake of dairy animals in winter and summer seasons

\begin{tabular}{|c|c|c|c|c|c|c|c|c|c|c|}
\hline \multirow[t]{3}{*}{ Items } & \multicolumn{10}{|c|}{$\begin{array}{l}\text { Small farms } \\
\text { (Buffalo) }\end{array}$} \\
\hline & \multicolumn{5}{|c|}{ Winter season } & \multicolumn{5}{|c|}{ Summer season } \\
\hline & Total & $\begin{array}{c}\text { Conc. } \\
\text { mix }\end{array}$ & Berseem & $\begin{array}{l}\text { Corn } \\
\text { silage }\end{array}$ & Straw & Total & $\begin{array}{l}\text { Conc. } \\
\text { mix }\end{array}$ & Darawa & $\begin{array}{c}\text { Corn } \\
\text { silage }\end{array}$ & Straw \\
\hline Fresh feed (kg) & 66.05 & 3.15 & 59.0 & 0.0 & 3.90 & 39.9 & 4.1 & 27.0 & 5.0 & 3.8 \\
\hline$\%$ & 100.0 & 18.30 & 59.04 & 0.0 & 22.66 & 100.0 & 27.18 & 35.80 & 12.15 & 24.86 \\
\hline DM (kg) & 15.49 & 2.84 & 9.15 & 0.0 & 3.51 & 13.58 & 3.69 & 4.86 & 1.65 & 3.38 \\
\hline $\mathrm{CP} \%$ & 13.87 & 0.45 & 1.55 & 0.0 & 0.14 & 9.78 & 0.59 & 0.44 & 0.17 & 0.14 \\
\hline TDN \% & \multicolumn{10}{|c|}{ Crossbred } \\
\hline Fresh feed $(\mathrm{kg})$ & 68.23 & 2.83 & 61.50 & 0.0 & 3.90 & 31.1 & 3.6 & 24.5 & 0.0 & 3.0 \\
\hline$\%$ & 100.0 & 16.31 & 61.16 & 0.0 & 22.52 & 100.0 & 31.0 & 42.79 & 0.0 & 26.20 \\
\hline DM (kg) & 15.59 & 2.54 & 9.53 & 0.0 & 3.51 & 10.31 & 3.20 & 4.41 & 0.0 & 2.70 \\
\hline СР \% & 13.91 & 0.14 & 1.62 & 0.0 & 0.14 & 9.86 & 0.51 & 0.40 & 0.0 & 0.11 \\
\hline TDN \% & 56.80 & 1.73 & 5.72 & 0.0 & 1.40 & 61.52 & 2.17 & 3.09 & 0.0 & 1.08 \\
\hline & \multicolumn{10}{|c|}{ Local (baladi) } \\
\hline Fresh feed $(\mathrm{kg})$ & 43.4 & 2.85 & 37.50 & 0.0 & 3.05 & 31.0 & 2.5 & 25.0 & 0.0 & 3.5 \\
\hline$\%$ & 100.0 & 23.06 & 52.26 & 0.0 & 24.68 & 100.0 & 22.73 & 45.45 & 0.0 & 31.82 \\
\hline DM (kg) & 11.12 & 2.57 & 5.81 & 0.0 & 2.75 & 9.90 & 2.25 & 4.50 & 0.0 & 3.15 \\
\hline $\mathrm{CP} \%$ & 13.56 & 0.41 & 0.99 & 0.0 & 0.11 & 9.0 & 0.36 & 0.41 & 0.0 & 0.13 \\
\hline TDN \% & 56.91 & 1.74 & 3.49 & 0.0 & 1.10 & 60.0 & 1.53 & 3.15 & 0.0 & 1.26 \\
\hline
\end{tabular}


دراسة فنية وإقتصادية مقارنة لنظم مزارع الألبان بقطاع غرب الدلتا

محمد محمد إسماعيل العشماوى'، حسن محمود بيومى سمور'، مصطفى عبد الرزازق إبراهيم

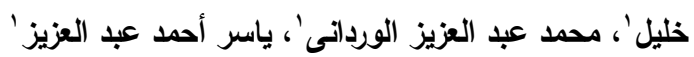

1 - معطج بحوث الإتتاج الحيواني، مركز البحوث الزياعية، الدقي، الجيزة، مصر، r - معهـ بحوث الإقتصاد

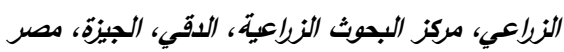

- اعتمد الدراسة على البيانات المتحصل عليها من خلال استمارة استيان تم تصميمها لتجميع البيانات. وقد

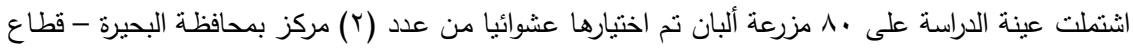

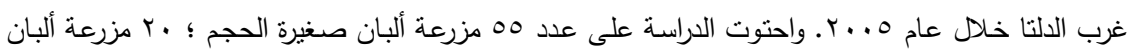
متوسطة الحجم ؛ م مزارع ألبان كبيرة الحجم. - هدفت الدراسة إلى التعرف على المشاكل الحقيقية الخاصة بتخذية الحيوانات ؛ الإنتاجية ؛ التناسل ؛ وكذلك الكفاءة الاقتصادية في استخدام موارد الإنتاج المثاحة.

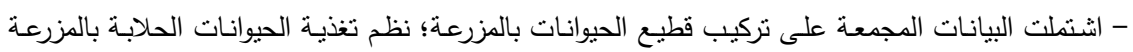

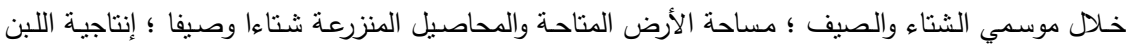

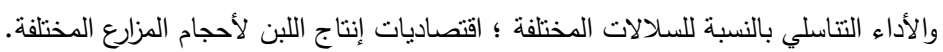

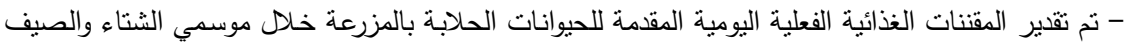

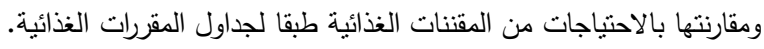

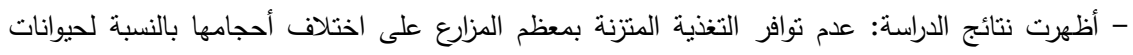

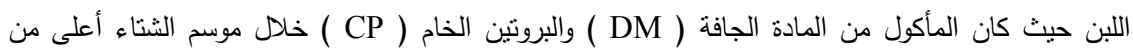

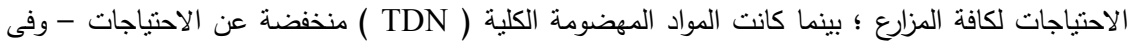

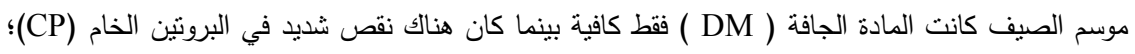

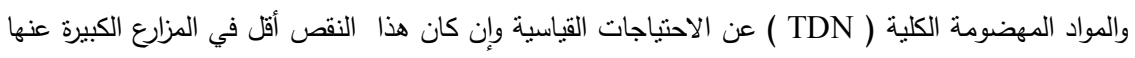

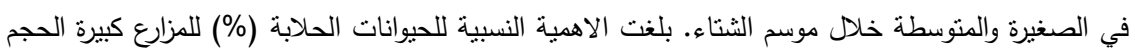

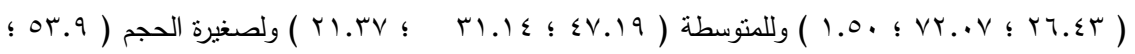

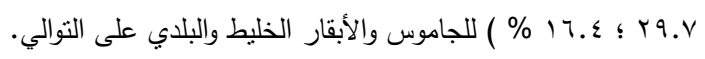

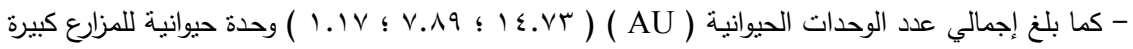
الحجم والمتوسطة والصغيرة على التوالي.

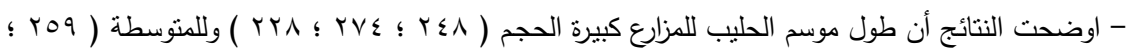

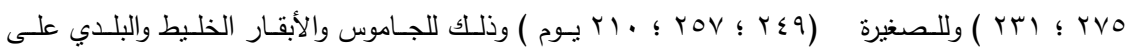




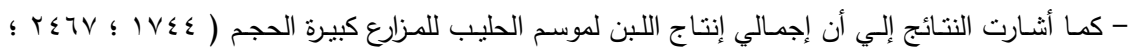

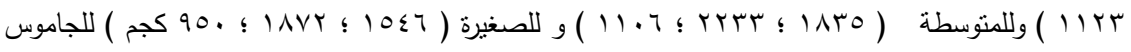

$$
\begin{aligned}
& \text { والأبقار الخليط والبلدي على النقالي. }
\end{aligned}
$$

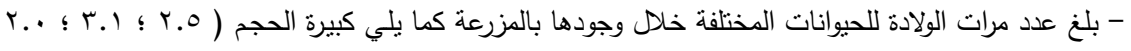

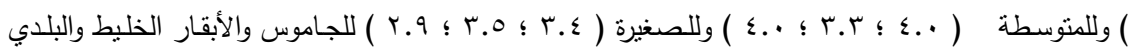

$$
\begin{aligned}
& \text { على التوالي. }
\end{aligned}
$$

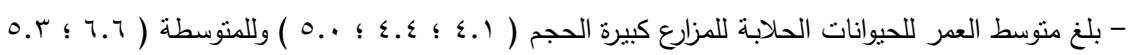

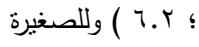

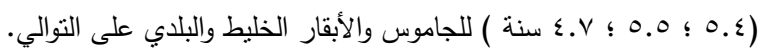

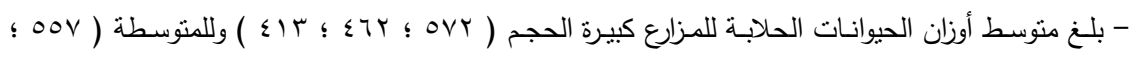

$$
\begin{aligned}
& \text { ( rM } \leq \leqslant T V
\end{aligned}
$$

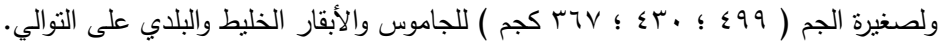

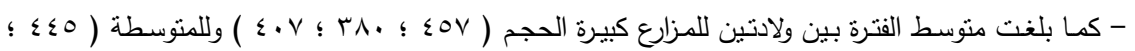

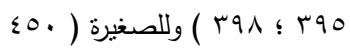

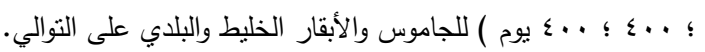

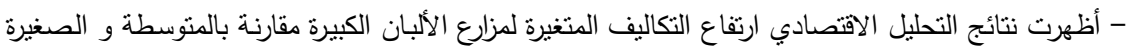

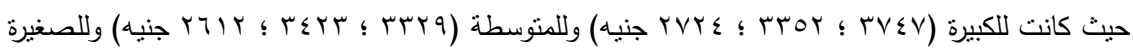

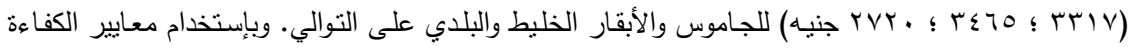

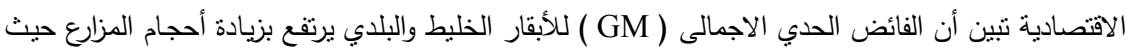

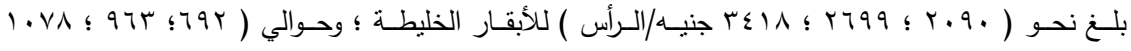

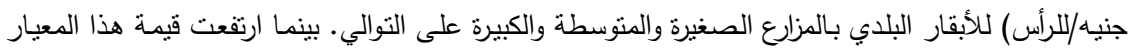

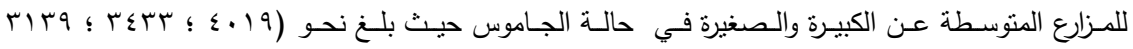

$$
\begin{aligned}
& \text { جنيه/لألسأس) على التوالي. }
\end{aligned}
$$

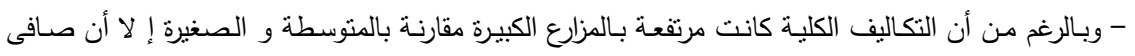

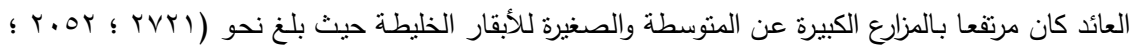

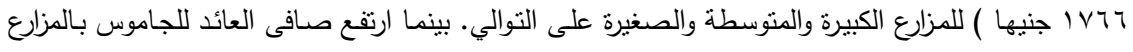

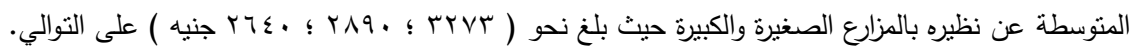

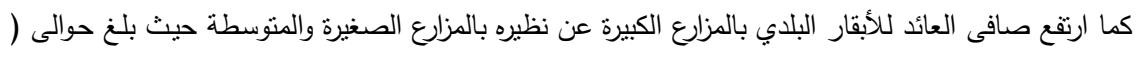

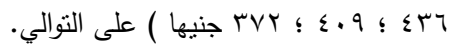

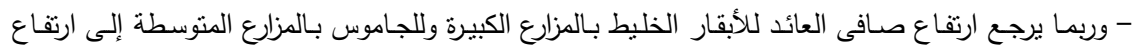

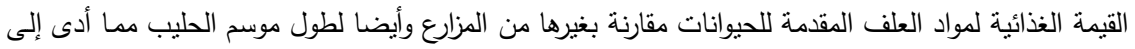

$$
\begin{aligned}
& \text { زيادة إنتاجية الحيوانات من اللبن. }
\end{aligned}
$$

